\title{
An analysis of some heavy metals in the water, sediments and some fishery organisms from Yewa Lagoon, Nigeria \\ ${ }^{1}$ Taiwo, I.O; ${ }^{2}$ Olopade, O.A.and ${ }^{2}$ Gafar, A.F.

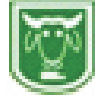 \\ ${ }^{1}$ University of Agriculture, Abeokuta (iomtai@yahoo.com) \\ ${ }^{2}$ Olabisi Onabanjo University, Ago-Iwoye
}

\begin{abstract}
The concentration of heavy metals $(\mathrm{Zn}, \mathrm{Ni}, \mathrm{Pb}, \mathrm{Cd}$ and $\mathrm{Cu})$ in the muscle of three fishery organisms (Chrysicththysnigrodigitatus, Sarotherodongalilaeus and Peneausmonodon)and in environmental samples of waterand sediment were tested in Yewa Lagoon, Nigeria. Five fishing villages along the lagoon were selected as the sample sites where these metals were tested. The heavy metal content in the muscle of the fishery organisms was $\mathrm{Zn}>\mathrm{Ni}>\mathrm{Pb}>\mathrm{Cu}$ $>\mathrm{Cd} ; \mathrm{Zn}>\mathrm{Ni}>\mathrm{Pb}>\mathrm{Cd}>\mathrm{Cu}$ and $\mathrm{Zn}>\mathrm{Ni}>\mathrm{Pb}>\mathrm{Cd}>\mathrm{Cu}$ inC.nigrodigitatus, S.galilaeus and P.monodon respectively. The heavy metal concentrations in the sediment was $\mathrm{Zn}>\mathrm{Pb}>$ $\mathrm{Cu}>\mathrm{Ni}>\mathrm{Cd}$. However, nickel and cadmium were not present in the water at two sampling sitesof Yewa Lagoon.The water of Yewa Lagoon is polluted with all the five heavy metals which were all higher than the WHO standard. The concentration of Zinc in the fishery organisms were below the WHO standard. However, the high concentration of zinc in the water (which is well above the WHO standard) could be associated with the fact that zinc is naturally abundant in Nigeria soils.
\end{abstract}

Keywords: Heavy metals, sediments, fishery organisms, lagoon,

\section{Introduction}

As ecosystems, estuaries are under threat from human activities such as pollution and overfishing. They are also threatened by sewage, coastal settlement, land clearance and much more. Estuaries are impacted by events far upstream, and concentrate materials such as pollutants and sediments (Branch, 1999). Land run-off and industrial, agricultural, and domestic wastes enter rivers and are discharged into estuaries. Contaminants can be introduced which do not disintegrate rapidly in the marine environment, such as plastics, pesticides, furans, dioxins, phenols and . Unlike many organic pollutants which eventually degrade to carbon dioxide and water, heavy metals tend to accumulate in the environment, especially in lake, estuarine or marine sediments. However, some heavy metals like copper and zinc are essential elements and are required in minute quantities (APIS, 2012).

Heavy metals is a general collective term applied to a group of metals with an atomic density greater than $4 \mathrm{~g} / \mathrm{m}^{3}$ (Duffus, 2002). Heavy metals include chromium, cadmium, arsenic, lead, mercury, copper, zinc, and boron. Heavy metals are elements which occur naturally in the Earth's crust. Accumulation of heavy metals in aquatic ecosystems is of global importance. Metals generally enter the aquatic environment through atmospheric deposition, erosion of geological matrix or due to anthropogenic activities caused by industrial effluents, domestic sewage and mining wastes (Eciukynaset al., 2004). The metal contaminants in aquatic systems usually remain either in soluble or suspension form and finally tend to settle down to the bottom or are taken up by the organisms. The progressive and irreversible accumulation of these metals in various organs of marine 
creatures ultimately leads to metal-related diseases in the long run because of their toxicity, thereby endangering the aquatic biota and other organisms (Mansour, 2002). Fishes being one of the main aquatic organisms in the food chain may often accumulate large amounts of certain metals (Bartramet al., 1999).This study was undertaken to examine the pollution status in Yewa lagoon, Nigeriathrough the assessment of the presence of heavy metals in the muscle of some commercially important fishery organisms ( Sarotherodongalilaeus, Chrysichthysnigrodigitatus and Penaeusmonodon) and the environment (water and sediment).

\section{Materials and Methods}

Five fishing villagesbordering the lagoon were selected from the 18 fishing villages based on the number of fishers, importance of activities associated with fishing and degree of isolation. At each site fishery organisms, water and sediments were sampled. Three fishery organisms namely:Sarotherodongalilaeus, Chrysichth $y$ s n i grodig itatus a n d Penaeusmonodonwhich are of commercial importance were sampled. $1 \mathrm{~g}$ of fish muscle was collected from each fish sample and digested to test for five heavy metals (copper, lead, zinc, cadmium and nickel). $1 \mathrm{~g}$ of fish muscle is first digested, using $15 \mathrm{ml}$ of nitric acid and $5 \mathrm{ml}$ of sulphuric acid. The digested solution is poured into sampling bottles with a little waterto dilute. The Atomic Absorption Spectrophotometer was then used to determine the levels of heavy metals inthe muscle of the fishery organisms sampled.

For water, $10 \mathrm{ml}$ of hydrochloric acid was poured into $100 \mathrm{ml}$ of the water sample todigest.It was left for 20 minutes in a fume cupboard.The solution would have reduced in volume, it is then filteredwith a little water and allowed to drop into the sampling bottlesand dilute with water.TheAtomic Absorption Spectrophotometer is then used to determine levels of heavy metals in the water samples.

For sediment, the sediment was put on a sheet of paper and air dried.The air dried sediment was put in a conical flask and $10 \mathrm{ml}$ each of nitric sulphuric acid wasadded and placed in a fume cupboard.Alittle water was added tothe digested solution and filtered into sampling bottles. It was then diluted with water and the Atomic Absorption Spectrophotometer was used to determine levels of heavy metals in the sediment samples.

The mean values for the heavy metals were determined in the parameters and line graphs were drawn using Microsoft Excel to show the trend of the heavy metals from the various fishing villages sampled. The data was subjected to analysis of variance (ANOVA) to determine the variation of heavy metals in the water body, fish muscle and sediments among the fishing villages.

\section{Results}

Table 1 shows the levels of heavy metals detected in the muscle of the fishery $\begin{array}{lllllllll} & \mathrm{r} & \mathrm{g} & \mathrm{a} & \mathrm{n} & \mathrm{i} & \mathrm{s} & \mathrm{m} & \mathrm{s}\end{array}$ (Sarotherodongalilaeus, Chrysichthysnigro digitatus and Penaeusmonodon) fromYewaLagoon, the water and sediments of the lagoon. The WHO minimum acceptable levels are in parenthesis (Table 1). The zinc content in the muscle of the fishery organisms are way below the WHO standard of $150 \mathrm{mg} / \mathrm{g}$ for acceptable limits in fish muscle (Table 1).

The Lagoon is polluted with nickel, WHO standard for nickel in fishery organisms is $0.4 \mathrm{mg} / \mathrm{g}$ and in water, $0.1 \mathrm{mg} / 1$. Of the three fisheryorganism, Nickel levels are highest in S.galilaeus $(14.94 \mathrm{mg} / \mathrm{g})$ and lowest in C.nigrodigitatus $(5.62 \mathrm{mg} / \mathrm{g})$. Lead and 
cadmium are also higher in $S$. galilaeus $(4.4 \mathrm{mg} / \mathrm{g})$ than in C.nigrodigitatus $(3.2 \mathrm{mg} / \mathrm{g}$ ) and P.monodon $(3.9 \mathrm{mg} / \mathrm{g})$. The WHO standard for lead is $0.01 \mathrm{mg} / 1$ for water and $1.5 \mathrm{mg} / \mathrm{g}$ for fishery organisms. Thus the lead levels in the Yewa Lagoon and fishery organisms are above the WHO safe standard level for safe consumption. The levels of Cadmium was lowest in C.nigrodigitatus $(0.52 \mathrm{mg} / \mathrm{g})$, compared to S.galilaeus $(4.01 \mathrm{mg} / \mathrm{g})$ and P.monodon $(3.75 \mathrm{mg} / \mathrm{g})$ with the water in Yewa Lagoon containing $0.64 \mathrm{mg} / \mathrm{l}$. These levels are high relative to the WHO values of $0.2 \mathrm{mg} / \mathrm{l}$ for water and $0.005 \mathrm{mg} / \mathrm{g}$ for fishery organisms. The concentration of copper in the water $(3.27 \mathrm{mg} / \mathrm{l})$ is higher than the WHO standard of $0.5-1 \mathrm{mg} / \mathrm{l}$. However, the copper levels in $S$. galilaeus $(0.77 \mathrm{mg} / \mathrm{g})$ was lower than the WHO standard of 1-3 while that of C.nigrodigitatus $(2.35 \mathrm{mg} / \mathrm{g})$ and S.galilaeus (2.76) are within the WHO tolerance levels'.

\section{Discussion}

The water in Yewa Lagoon can be said to be polluted $(22.93 \mathrm{mg} / \mathrm{l})$ with Zinc, the WHO standard of $3.0 \mathrm{mg} / 1$. The high concentration of zinc in the water could be associated with the fact that this metal is naturally abundant in Nigeria soils and since the source of metal depositories are the aquatic systems (Kakuluet al., 1988; Nwajeietal., 2001; Adefemietal., 2008). The fishery organismsinvestigated contained heavy metals at a concentration higher than the World Health Organization (WHO) standard. Hence, one may conclude that the level of heavy metals in the samples analysed could constitute a health hazard. On this basis fishery organisms from the Yewa lagoon could be considered unsafe for human consumption and the need for continuous monitoring to prevent bioaccumulation is necessary (Adefemiet al., 2008).

The levels of Zinc, Copper and Lead detected in the sediment samples were $26.61 \mathrm{mg} / \mathrm{g}, \quad 2.81 \mathrm{mg} / \mathrm{g}$ and $9.2 \mathrm{mg} / \mathrm{g}$ respectively with zinc having the highest concentration. Nickel and cadmium was not present in the sediment sample. The presence of zinc, copper and lead may be due to human activities such as the discharge of untreated sewage and uses of metals and industrial materials that contain metals as well as the ability of the sediment to act as a sink (Benedict et al, 1991; Kakuluet al., 1988). However, these levels are much lower than that given by the Consensus-Based Sediment Quality Guidelines (CBSQG. This indicates that the levels of heavy metals in the sediment are within or lower than acceptable limits.

\section{Conclusion}

Analysis of water, fishery organismsand sediment reveals that the Yewa Lagoon is contaminated by certain heavy metals. The water of Yewa Lagoon is polluted with all the fiveheavy metalswhich were all higher than the WHO standard.Zinc levels

Table 1: Mean values for heavy metals(ppm)

\begin{tabular}{lccccc}
\hline & Copper & Zinc & Cadmium & Lead & Nickel \\
\hline C. nigrodigitatus & 0.024 & $0.222(15)$ & $0.052(2)$ & $0.032(6)$ & $0.056(0.04)$ \\
S. galilaeus & 0.078 & 0.192 & 0.040 & 0.044 & 0.149 \\
P. monodon & 0.028 & 0.208 & 0.038 & 0.039 & 0.119 \\
Sediment & 0.028 & 0.266 & 0.006 & 0.092 & 0.035 \\
Water & $3.27(0.5-1)$ & $22.93(3)$ & Nil & $2.9(1)$ & Nil( 0.1$)$ \\
\hline
\end{tabular}

* Figures in parenthesis is the maximum acceptable limits (Choi, 2011); 
An analysis of some heavy metals in the water from Yewa Lagoon, Nigeria
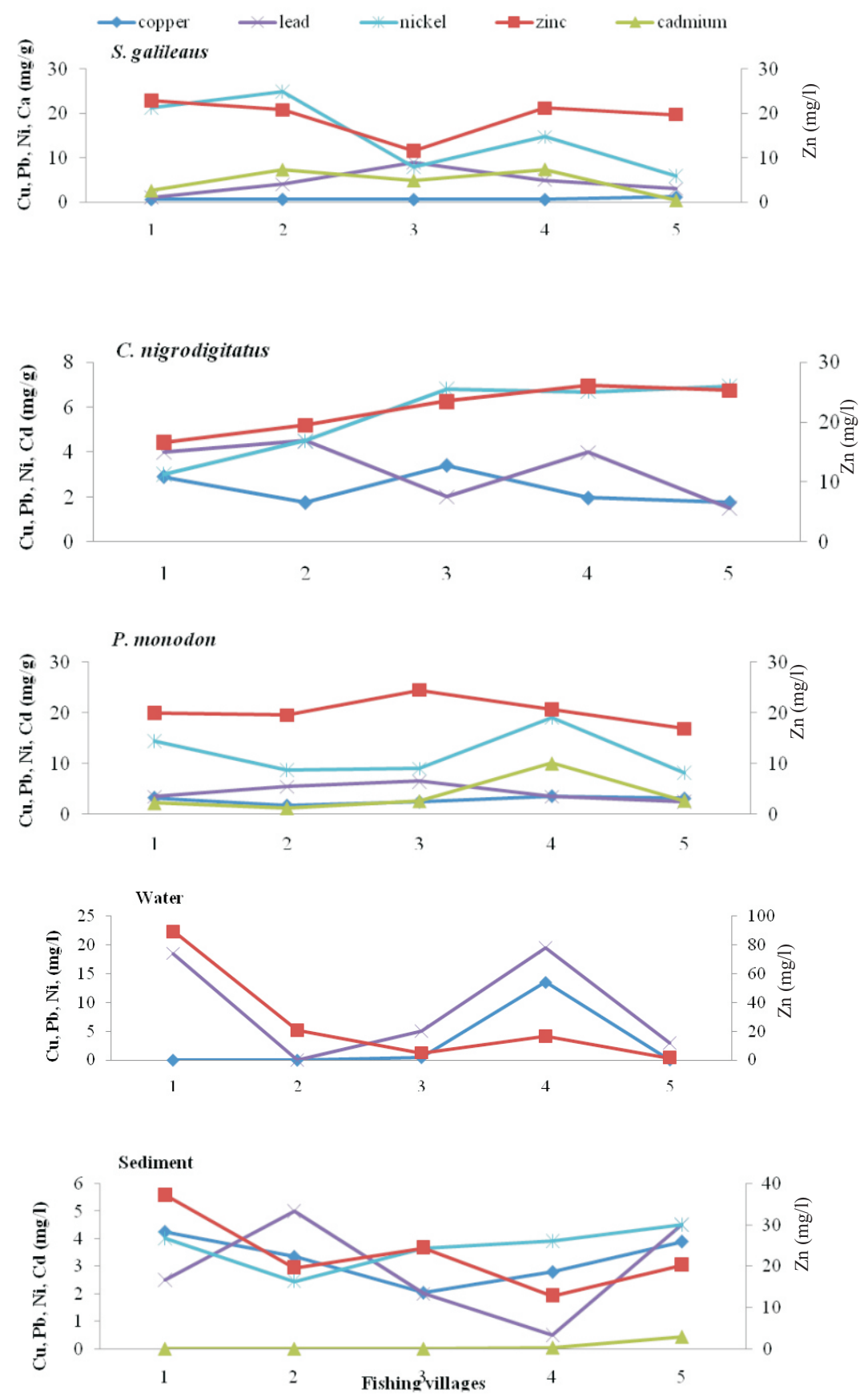

The graphical trend of the levels of heavy metal concentration between the fishing villages is shown in Figure 1. 
concentration in the catfish, tilapia and shrimp were below the WHO standard. However, the high concentration of zinc in the water (which is well above the WHO standard) could be associated with the fact that zinc is naturally abundant in Nigeria soils. Also the Lead levels in the waterand fishery organismsare quite high indicating that the water and aquatic organisms in Yewa lagoonare not fit for human consumption. The concentrations of the heavy metals in the sediments of Yewa lagoon are either within or lower than acceptable limits withzinc $>$ copper $>$ lead. Nickel and cadmium was not present in the sediment. This high level of heavy metal pollution of Yewa lagoon and its fisheries resources is of great concern considering its location and its dependence on the livelihood of the people. The fishery organismsare sold in the heavily metropolitan city of Lagos and the water is used for domestic purposes.It is therefore, of immediate concernthat the Lagoon be protected from further pollution.

\section{REFERENCES}

Adefemi, S.O, Asaolu, S.S and Olaofe, O. 2008..Res J Environ Sci.2(2): 151155.
A P I S ,
2010
http://www.apis.ac.uk/overview/poll utants accessed July 21, 2012

Atta, M. B, Els-sebale, L. A, Naoman, M. $A$ and Kassab, H. 1997. Food
Chem.58: 1-4.

Bartram, J., Wayne, W. Carmichael, I. Chorus, Gary Jones, and O. M. Skulberg. 1999. In: Toxic Cyanobacteria in Water: A guide to their public health consequences, monitoring and management. World Health Organization. URL: WHO document

Benedict, C., Okoye, O., Afolabi, O.A. and Ajao,E.A. 1991. Int $J$ Environ Stud., 37 (1 and2): 35-41.

Branch, G. 1999. Estuarine vulnerability and ecological impacts, TREE vol. 14, no. 12 .

Duffus, J.H. 2002 . Heavy metals - A meaningless term.Pure and Applied Chemistry. 74: 793-807.

EPA. (Environmental Protection Agency) 2004. "Report to Congress: Impacts and Control of CSOs and SSOs." . Document No. EPA-833-R04-001.http://www.epa.gov

Kakulu, S.E and Osibanjo, O. 1988..Nigerian J. Chem. Soc., 13: 911.

Mansour, S.A. and Sidky, M.M., 2002..Ecotoxicological studies. 3: Heavy metals contaminating water and fish from Fayoum Governorate, Egypt. Food Chem., 78: 15-22.

Nwajei, G. E and Oruvwuje, O. 2001. Pak J Sci Ind Res., 44, 333-337.

Received: $4^{\text {th }}$ January, 2014

Accepted: $28^{\text {th }}$ May, 2014 